\title{
28 Global corporations and the governance of standards
}

\author{
Jean-Christophe Graz
}

\section{INTRODUCTION}

The new wave of globalization backlash upon which populist movements have capitalized worldwide blames skewed rules in favour of the most privileged individuals and largest firms. The 'us versus them' uprising not only targets the establishment, free trade and the impunity of global finance in the wake of the global financial crisis, it also sees global corporations as increasingly able to set rules and solve disputes on their own terms. Be it the Canada-European Union Comprehensive Economic and Trade Agreement (CETA), the aborted Transatlantic Trade and Investment Partnership (TTIP) or the Trans-Pacific Partnership (TPP) among Asia-Pacific countries, the authority gained by technical standards presumably set in favour of the most powerful global corporations has swiftly become among the most contentious issues in negotiations besides investor-state dispute settlements mechanisms. European fears over the abolition of food safety standards standing in the way of importing 'Frankenfood' such as chlorinated chicken or hormone beef from the United States may be exaggerated. Yet, conflict-ridden negotiations for such mega trade deals do include provisions for greater mutual recognition of standards, and plans to set new regulatory councils in charge of designing future regulatory convergence around the type and scope of technical standards to be recognized in government regulations (Cai 2016; De Ville and Siles-Brugge 2016; OECD 2016; Pitschas 2016; Magnette 2017). Responding to the 'us versus them' discourse feeding populism and the latest wave of the globalization backlash thus supposes being able to understand who is in charge of shaping market power and determining market access. With regard to standards defining a common set of characteristics which particular goods or services are expected to conform to, the question is: to what extent are global corporations able to set standards in their own interests and ensure that such standards exercise a form of alternative authority to conventional state regulation and intergovernmental agreements?

Conventional accounts emphasize global welfare benefits to standardization. Rather than lengthy processes set by public authorities for defining mandatory regulations, standards set within standard-setting organizations - be they completely private or involving government ministries at varying degrees - are seen as timely and efficient tools of coordination that help to overcome market failures and serve a crucial role in research and development strategies of innovation (as for high-technology or interoperability standards), commercialization and technological diffusion. Insofar as appropriate mechanisms are in place to avoid anti-competitive behaviour and regulatory capture, standards are thus understood as ultimately yielding substantial benefits to consumers' welfare (Blind and Gauch 2009; Swann 2010; Viardot et al. 2016). Yet, no simple answer exists regarding such inclination towards monopolistic behaviour. Moreover, standards touch 
on far-reaching issues beyond mere industrial and consumers' choices, market failures, technological innovation and competition. A number of studies thus look beyond the environment of the firm and welfare economics to understand how standards themselves reflect distinct power relations in their claim to bring more quality and efficiency to regulatory authority (Brunsson and Jacobsson 2000; Hallström 2004; Murphy and Yates 2009; Timmermans and Epstein 2010; Busch 2011; Ponte et al. 2011; Graz 2015). This chapter draws on such scholarship to forge a global political economy perspective that puts emphasis on the comprehensive foundation of power relations involved in the regulatory authority of standards, and on their evolving variety across borders. It argues that standards reflect a form of hybrid governance over which global corporations have much hold, and which increasingly competes with previous rules governing markets, and more generally the social foundations of state power.

The chapter begins with some background on standards and their role in shaping market regulation and creation. It then examines the institutional environment in which global corporations uphold considerable leverage in setting standards. After that the analysis provides some insights on why global corporations are in a position to take advantage of such hybrid forms of governance in contemporary global capitalism. The conclusion wraps up the argument and draws further implications.

\section{STANDARDS SHAPING MARKETS}

'Standards' refer here to voluntary technical specifications explicitly documented and published as tools for the organization of production and the exchange of goods and services. Standards codify technical specifications regarding measurement, design, performance, as well as side effects of products, industrial processes and services. This includes almost any type of product, process or service. It can be as mundane as metric and arithmetic definitions; for example, thread lengths for bolts and nuts (ISO 888). But it also takes in intricate business models qualifying the ability of a firm to disaggregate and complete complex tasks, such as the Capability Maturity Model Integration in the field of services (CMMI for Services) of the CMMI Institute, a technology commercialization enterprise working as a subsidiary of Carnegie Mellon University and sponsored by the United States (US) Department of Defense. The relatively broad definition of standards given above acknowledges a difference between formal standards and other norms that arise from unintentional actions and habits (Ponte et al. 2011, p.2). Formal standards are set by entities dedicated to such purpose, be they national standard bodies, members of the International Organization for Standardization (ISO), industry-based standards developing organizations such as those existing in the United States, research centres and management consultancy firms supporting business models, as well as consortia of firms and organizations working together to develop technical specifications such as the World Wide Web Consortium (W3C) that has designed many web formats and protocols (HTTP, HTML, XML, and so on). Whoever sets formal standards, expected compliance mechanisms do exist in the form of various conformity assessment processes and certification procedures, with some sort of sanction for non-compliance.

Similarly, the definition used above acknowledges a distinction between technical specifications used in regulations set by public authorities, and those that are voluntary 
and thus formally outside of the mandatory rule of the sovereign state. There is, however, considerable overlap between mandatory standards embedded in public regulations, and voluntary specifications set by standard-setting bodies. Both types of instruments are so much intertwined that studies on legal pluralism refer to such concepts as internormativity or transnational private regulatory governance to describe recent developments in which the law faces much difficulty in ordering such differentiated societal activities (Frydman 2014, p. 33ff; Zumbansen 2015). A landmark report that the World Trade Organization (WTO) published on non-tariff measures is unequivocal in that regard:

Although cast as 'voluntary' in nature (because they are imposed by private entities), private standards (for example ISO \& other standards) may become de facto a necessary condition for market access even if not imposed by law ... the effect of a particular private standard, if pervasive, could be greater than that of a government regulation of a smaller country. (World Trade Organization 2012, p. 211)

Public authorities have actively encouraged the use of private standards and supported their adoption in mature and emerging technologies (EXPRESS 2010; National Science and Technology Council 2011; JISC 2013; European Commission 2016a). From this perspective, a more extensive use of standards reflects a shift in the articulation between the public and the private spheres, rather than a mere voluntary tool of market organization. Yet many existing legal provisions still do not take full account of such developments, and confine international standards to the domain of private voluntary market tools provided by private firms. ${ }^{1}$ Moreover, the overlap between state regulation and supposedly voluntary private standards is reinforced by the wide range of institutional bodies entitled to confer authority to standards, let alone the numerous actors involved in standard-setting procedures (Djelic and den Hond 2014). As Busch points out, 'private standards and public regulations are two similar and sometimes overlapping forms of governance' (Busch 2011, p. 27). In what follows, I examine the institutional environment that grants international standards this quasi-official status in technical specifications used for market access of goods and services worldwide.

\section{INSTITUTIONS SHAPING STANDARDS}

For many decades, many technical specifications were set within the regulatory framework of law, and only complemented by standards set by companies and, to a marginal degree, national standardization bodies. Today, the regulatory framework of law has yielded ground to voluntary standards drafted by a wide range of international or regional standards-developing organizations (SDOs). The creation of the World Trade Organization in 1995 marked a critical juncture. In contrast to the relatively loose provisions of the General Agreement on Tariffs and Trade (GATT) in place before, the Agreement on Technical Barriers to Trade (TBT), the Agreement on Government Procurement (GPA), the review of the Agreement on Sanitary and Phytosanitary Measures (SPS) and the General Agreement on Trade in Services (GATS) grant international standards a major role in the harmonization of technical specifications applicable to goods and services. State regulation in this domain must comply with 'legitimate objectives', such as health, safety and environmental issues. The goal of removing 'unnecessary' barriers to trade 
should furthermore be pursued as far as possible by substituting domestic standards for 'relevant international standards'.

Reviewing to what extent governments draw on international standards in their technical regulations as mandated by the WTO Agreements remains, however, an intricate task. Ironically, the lack of harmonized standards and the incompleteness of existing data hinder the possibility to obtain a reliable and systematic view of the matter. However, tentative studies confirm the receptiveness of policy and regulation to the use of international standards (Fliess et al. 2010; Choi 2013). Be that as it may, existing provisions still grant many international bodies the ability to define such standards. In order to maintain a shared threshold of institutional isomorphism despite important variations among the most powerful actors of the world trade system, the TBT committee of the WTO eventually established principles to ensure transparency, openness, impartiality and consensus, effectiveness and relevance, coherence, as well as guarantees to address the concerns of developing countries. ${ }^{3}$ Such principles primarily seek to address the differences between the ISO and the European environment on the one hand, and the American institutional framework for setting standards on the other. The two systems reflect what institutional analyses call a case of 'regulatory competition' between coordinated and liberal market economies where domestic institutional complementarities play a key role (Czaya and Hesser 2001; Tate 2001; Winn 2009; Mattli and Büthe 2011). The ISO/European system favours a coordinated standardization system with greater reliance on territorially based legitimacy and state oversight; the American system gives preference to competing sources of standards, including those set by ad hoc consortia within distinct industries such as in information, communications or telecommunications, and relies on market mechanisms to ensure their definition and adoption.

This prompts us to examine further the relation between the ability of global corporations to set technical specifications within a market economy, and the political environment of the institutional framework required to confer a legitimate authority on such practices. The remainder of this section provides an overview of activities related to standards developing organizations (SDOs) focused on their two most distinct institutional environments: the European and the American system.

In 1985, the European Council Resolution 85/C 136/01 on a 'New Approach' to technical harmonization and standardization instigated a new regulatory technique and strategy. Although member states were suspicious about seeing regulation in this domain transferred to the European authorities, they did perceive the threat of a race to the bottom in public purpose standards as market integration progressed. The New Approach provides a framework for the harmonization of European Union (EU) mandatory regulation only on the general and essential requirements of goods traded on the European market, in particular in the fields of health, environment, safety and consumer protection. Depending on the sectors affected, technical specifications, performance criteria and quality requirements are either based on mutual recognition of national standards, or delegated to European standard-setting bodies. In most sectors, the procedure for monitoring standards is a matter of business self-regulation, since products put on the market are granted a presumption of conformity, solely based on the declaration of the manufacturer (CE marking). The entry into force in 2013 of a new Regulation on European standardization (1025/2012) and the adoption in 2016 by the European 
Commission of a 'standardization package' extended those principles to a number of domains, while at the same time reinforcing the support for civil society stakeholders and small and medium-sized enterprises (SMEs). It provides for educative and incentive actions geared to support greater awareness, cooperation, transparency and inclusiveness. Thus, the European system has done more than strengthen the ability of companies to rely on voluntary standards rather than mandatory regulation in the Single Market. By avoiding costly third-party testing and certification, by addressing concerns with regard to its democratic deficit, and by providing procedural means for a simultaneous adoption of European standards as international ones (through the so-called Dresden and Vienna Agreements), the European Union has also included third parties and third countries in its standardization system. The (largely unintended) outcome has been a powerful strategic positioning of European standards in the global market (Vogel 1995; Egan 2001; Borraz 2007).

In the United States, standardization is more fragmented, and organized on a sectoral basis. A variety of competing standards organizations (formal and informal) set marketdriven standards clearer of state intervention than in the European environment. The system follows a so-called model of direct participation, where companies have direct access to standard-setting activities with international claims. Hundreds of private sectoral bodies exist in the United States. Among them, a dozen make up more than 90 per cent of standards produced, especially in the petroleum, automotive and other technologydriven industries. And only three players can claim a global standing, with a wide use of their tools beyond their sectoral and territorial basis: Underwriter Laboratories (UL), the American Society of Mechanical Engineers (ASME) and ASTM International (originally known as the American Society for Testing and Materials). With half of its standards sold being purchased outside the United States, ASTM International stands out, notably as a result of an active policy of Memoranda of Understanding signed with more than 100 national standards bodies, mostly in developing and emerging countries (Saudi Arabia, Columbia and Turkey being the three countries most referencing those standards). Moreover, the United States standards landscape not only includes sectorspecific activities and specialized organizations such as ASTM International: to a greater extent than in the EU, technical specifications are set within alliances in which government agencies and private companies, associations and SDOs collaborate to develop so-called consortia standards, such as the W3C and the Internet Engineering Task Force (IETF) developing joint specifications for the Internet, cyber-security and other information and communication technologies. The United States also gave rise to the Open Source movement. In contrast to the proprietary and closed dimension of most consortia standards, Open Source standards such as the Open Office suite or the bibliographic software Zotero are based on specifications (mostly computer codes) set collectively in an evolving and cumulative process, involving continuous sharing of information over the Internet (Cargill and Bolin 2007; Choi 2013).

However, the opposition between the European system and the American institutional framework should not be overstated (Egyedi 2005; Graz and Hauert 2014). Framing the institutional environment of standardization in such a way tends to reflect the lenses of institutional approaches rather than standardization practices themselves. The European and American standardization systems have more common characteristics than is usually imagined. Both rely on private companies to shape standards on a voluntary basis. They 
follow a due process open to all interested parties, and their deliberations are based on the 'state of the art'. The draft standards are subject to public consultation, and the general interest is supposed to prevail over particular interests. They recognize the primacy of international standards, even though the understanding of what 'international' means still remains controversial in the United States Standards Strategy (USSS), in spite of the substantial revision passed in 2005 for the specific purpose of better addressing such needs. Last but not least, both realize that the participation from the weakest stakeholders is in such short supply that it undermines the legitimacy of technical specification supposedly favouring the public interest. This is why recent policies on both sides of the Atlantic have taken initiatives supposedly geared toward supporting the participation of civil society organizations. The US standards strategy points out that 'government should recognize its responsibility to the broader public interest by providing financial and legislative support, and by globally promoting the principles of our standardization system' (American National Standards Institute 2016, p. 12). For its part, Annex III of the EU Regulation $1025 / 2012$ set the legal framework to better incorporate societal framework, and the publication in 2016 of the Standardisation Package includes actions that seek to enhance their representation in both the European and the international system.

Despite these similarities, several conflicts remain between European and American SDOs. The initiatives detailed in the latest version of the US strategy include a number of proposals that bring to mind the recent EU package, such as strengthening participation by the government in the development and use of voluntary standards, addressing the needs of consumers, promoting a worldwide application of 'internationally recognized principles' (that is, WTO compatible) in the development of standards, as well as a number of provisions driven towards education and research. Yet, the US strategy still claims that 'market-driven, private sector-led approach to global standardization [privileged in the US] is substantially different from the approach favored in many other countries' (American National Standards Institute 2016, p.4). From the American point of view, the national participation model in the European standardization bodies gives them a substantial advantage at the international level (Zuckerman 1996, p.40; Czaya and Hesser 2001, p. 32). Both the Vienna agreement between the ISO and the European Committee for Standardization (CEN), and the Dresden agreement between the International Electrotechnical Commission (IEC) and the European Committee for Electrotechnical Standardization (CENELEC) can indeed be seen as benefiting European actors, as they grant provisions for the adoption of European standards as international ones, and have ensured a coordination of the standardization work between those organizations. Moreover, the European system sets up technical barriers to American firms through the distinct role it grants to the European standardization bodies. From a European point of view, the decentralized and fragmented standardsetting procedures in the United States represent a barrier to the US market. Moreover, American SDOs' claims to serve the public interest often hinder strong commercial interests and contending regulatory competition. Finally, the international reach of standards developed in the United States tends to undermine the authority of formal standardization arenas such as the ISO and CEN, even if recent trends suggest a greater convergence between both systems, with a greater use of ISO-compatible standards by American SDOs (Choi 2013).

Regardless of the similarities and differences between the European environment and 
the American institutional framework for setting standards, SDOs must comply with the due processes established by the WTO in order to produce internationally recognized principles' likely to be accepted as legitimate regulatory tools. This is why SDO membership and participation in technical committees are formally open to all interested parties, and voluntary. Yet, as will be seen below, the largest market actors keep dwarfing committees, civil society organizations are most often missing, and the participation of emerging countries remains relatively low when compared to their rising prominence in the global economy. In other words, global corporations from leading industrialized countries enjoy much power in setting standards, which more often than not serve as alternatives to conventional state regulation.

Just as a proper appraisal of the use of standards is fraught with pitfalls, since no systematic and official disclosure exists on the matter, it is impossible to accurately estimate the participation of distinct categories of stakeholders in standard-setting procedures. This is even more the case at the level of the working groups actually drafting standards, whose participants serve as technical experts rather than national delegates. Nevertheless, a study ordered by the European Commission prior to recent reforms on the access to the European standardization system by distinct interested parties provides some ballpark evidence. Taking the participation of the business community as a yardstick, the number of technical committees in which experts from consumer organizations, environmental organizations and trade unions participate is estimated as, respectively, 'rather low', 'even lower' and 'very low'. Despite those poor results, it is striking that, when European and international standardization bodies such as the ISO are compared, about a quarter of national standardization bodies still perceive the former as easier or much easier to access (EIM Business \& Policy Research 2009, pp. 81, 98). Once again, those are only estimates, often biased by the favourable view publicized by the organizations surveyed via web questionnaires. The entry into force of EU Regulations 1025/2012 introduced new processes that improved the monitoring and participation of stakeholder organizations representing the interests of consumers, workers and SMEs, and environmental interests. Yet, the first evaluation undertaken under those new commitments euphemistically points out that such participation 'is still challenged', notably because of the weak position and different capacities in terms of stakeholders' representation at national level, as well as a lack of inclusiveness at the international level (European Commission 2016b, pp.4, 11-12).

The few studies based on actual data corroborate such findings. For instance, comprehensive data collected on the inventory of all participants in ISO/CEN mirror committees established within the Swiss Standardization Association (SNV) in 1987, 1997 and 2007 show that business representatives were present in more than 90 per cent of so-called national 'mirror committees' in which ISO or CEN draft standards are discussed prior to taking part in international meetings. For their part, consumer representatives took part in 18.2 to 20.8 per cent of the committees, with one association alone accounting for more than a quarter of consumer participation (Hauert 2010). This can only bode ill for participation of civil society organizations in ISO and other international meetings, as experts taking part are chosen among such national mirror committees. For instance, consultants, representatives of the industry and of standards organizations themselves account for more than 70 per cent of all participants to plenary meetings of the technical committee in charge of the well-known series ISO 14000 of environmental management 
standards (Morikawa and Morrison 2004). Finally, descriptive statistics on participation by stakeholders' groups often reflect dummy data with regard to the ability of corporate representatives to organize themselves and defend their interests on a truly global level. Personal observations drawn from a 'research-action' project, devised to support the direct participation of civil society organizations in arenas setting international standards, witnessed a number of cases of unambiguous power plays in which, for instance, the preferences of one representative of an umbrella industry association prevailed over a much larger number of disparate stakeholders' voices (Hauert et al. 2016).

As a final point, there is still very little commitment from developing and emerging countries in standard-setting processes. A core group of six countries share the responsibility of secretariats for approximately 75 per cent of all ISO technical committees and subcommittees. However, while China has recently joined this group, which also includes Germany, the United States, Japan, France and the United Kingdom, approximately one-quarter of the 72 secretariats under the responsibility of the Standardization Administration of the People's Republic of China (SAC) take the form of twinning partnerships involving standardization bodies from industrialized countries. In contrast to the case of China, the involvement of SDOs from other large emerging countries has not increased much. For instance, both the Bureau of Indian Standards (BIS) and the Associação Brasileira de Normas Técnicas (ABNT) share less than ten ISO secretariats. Figures regarding experts who actively participate in the development of ISO standards are of the same type (Afnor 2016). Similarly, as seen above, more than 100 developing and emerging countries have signed memoranda of policy with ASTM International, but remain to a large extent standard takers rather than standard makers. In a nutshell, although ISO and SDOs such as ASTM International have taken a number of measures to support participation from developing-country members, the ability of large corporations from emerging countries to engage with standard-setting processes remains much more limited than in industrialized countries.

\section{THE TRANSNATIONAL HYBRID AUTHORITY OF STANDARDS}

In what has become a classic article of economics, Akerlof (1970) provided an important argument of why global corporations use standards in modern markets. As markets may face major information asymmetries, such as with variable qualities of used cars, sellers have information about the goods to be sold which buyers do not possess. Such asymmetry prevents the market from working properly and can eventually lead to its collapse. Developing standards of minimum quality becomes a crucial tool to help in rectifying this. There is, however, another rationale for standards. In contrast to defining some uniform qualities or interoperability requirements upon which market agents rely in their transactions, standards are also designed to differentiate. Standardized, yet differentiated products and services are, as Busch highlights, "produced simultaneously to be standard (when compared to each other) and differentiated in space or time (when compared to other products or services), to create a niche targeted at some (larger or smaller) group of persons' (Busch 2011, p. 165, emphasis in original). One of the clearest ways in which standards are used to differentiate is in their ability to reinforce path-dependant monopolistic and oligopolistic trajectories in technological innovation (David 1985; Mock 2005). 
Accordingly, a number of prominent cases of standards wars have occurred over many decades. While the rivalry between VHS and Betamax formats of video cassettes recorders and the subsequent DVD/DivX battle have become iconic, new duels occur constantly between competing standards. If resolved, they provide to the winner an opportunity to capture all gains of the market ; if not, they create a risk of sinking it altogether (Shapiro and Varian 1999). Today, new energies devoted to such standards wars are focused on the Internet of Things and the wider interconnectivity framework on which global corporations rely to increase their power in platform capitalism (Bratton 2015; Tilley 2016).

Such a political economy of innovation has led Dudouet et al. (2006) to conceive standardization as a process of appropriation with significant incidence on market power and competition. Although they do not grant exclusive exploitation rights as with patents, standards do codify technical specifications that can de facto exclude alternative technology and contending processes. Innovative technology conforming to such standards often includes patented technology, for instance in large-scale and forward-looking information technology-enabled business services relying on extensive databases and complex algorithms. Such neo-Schumpeterian lenses provide a persuasive explanation as to why large firms are likely to use standards for maintaining their domination on distinct technologies. It is less focused, however, on how the power of such standards redefines the articulation between the economic and political spheres. Moreover, the approach tends to overlook the extent to which the issue to be standardized affects the power configurations at stake. For instance, to what extent can the establishment of sustainability standards - including labour, environment and gender provisions - be clearly distinguished from standards established as instruments to develop technical interfaces for platforms such as Uber, Amazon Web Services or Google? Finally, neo-Schumpeterian approaches do not explicitly examine how international standards may undermine the constitutive principles of the territorial sovereignty of states; and, conversely, the role that states and intergovernmental organizations play in supporting the authority of international standards deserves further attention.

In order to respond to these shortcomings, a first step is to elaborate upon what I call the 'transnational hybrid authority' of standards. The concept describes a form of authority based on the ambiguous juxtaposition of instances of power transforming the relation between transnational capitalism and territorial sovereignty. The notion of hybridity is often used to serve as a handy default attribute to describe the complex features of contemporary global governance. Used in such a way, however, it is likely to reinforce - not to qualify or clarify - the latest wave of the globalization backlash. Rather than a default attribute, the notion of hybridity conveys here more generic attributes likely to help us make sense of the ability of standards to shape market access and regulation in contemporary capitalism. Insights from science, technology and society (STS) studies or post-colonial studies may differ as far as their theoretical foundations are concerned. Yet, they come together in viewing ambiguity as the prevailing feature in the criteria that define hybridity. A conceptual linchpin in Latour's analyses that gave rise to STS studies, hybrids describe 'quasi-objects' mediating nature-society relations: they reflect the erosion of the great divide that modernity failed to establish between society and nature, humans and non-humans, society and science (Latour 1991). To some extent, the notion of hybridity also established the very field of post-colonial studies, with a focus on blurred subjectivities and identities of the colonized subjects and their ability, in the ambivalence of the 
post-colonial encounter, to craft moments of 'historical agency' (Bhabha 1994, p. 208). Far from a vague combination of actors involved in global governance, ambiguity thus reflects an ontological property of the new tools of global governance to which standards fully belong.

The nature and the implications of the ambiguity upon which rests the ability of global corporations to set standards that subsequently shape market organization, access and regulation calls for a more detailed analytical framework. A vast literature on the rise of non-state actors and private authority has mushroomed against the backdrop of globalization (Cutler et al. 1999; Graz and Nölke 2008; Guzzini and Neumann 2012; Payne and Phillips 2014; Abbott et al. 2015). Such scholarship views globalization as a joint process of state power and market forces, with new patterns and agents of structural change through formal and informal power and regulatory practices. With so much emphasis on the actors gaining authority in private regulatory tools, the literature tends, however, to overlook the scope of regulatory practices involved, and the reconfiguration of the spatial structure in which such practices are implemented. This prompts us to aggregate the three following categories: not only the actors (who have the authority to set standards) but also the objects (what is standardized) and the space (where and whence standards are implemented). They provide a comprehensive yet differentiated picture of the wide range of actors involved in setting standards, the breadth of issues concerned, and the deterritorialization of sovereignty conveyed by the multiple systems of certification and accreditation worldwide. I examine those three dimensions in more detail below.

The first dimension of the framework is the 'institutional continuum' of actors in the public and the private spheres. As laid out earlier, there is much ambiguity on situating standards along this continuum, and that ambiguity plays its part in conferring authority on a range of corporate actors previously denied such capacity. Market forces and policy choices both affect the ability of agents to influence standardization, although in various ways. Technical specifications belong to the private sphere of economic activities governed by market constraints: they affect social and technological change from that angle. However, they remain related to the public sphere of political action and regulatory policies directed toward the general interest of society; for instance by determining a certain level of risk and setting principles of liability borne by global corporations or, a contrario, by allowing their rent-seeking behaviour and market power. Hence, even in the circumscribed field of technical specifications, norms relate as much to capital accumulation and technical progress as to social improvement or various instruments of the welfare state.

The second dimension thus charts the 'material continuum' that outlines what can be standardized along the two poles of the physical and societal worlds. In aggregating the relationship between human beings and nature, technical specifications range from natural and invariable physical measures to constructed and historically bound societal values. This dimension highlights the extended scope of international standardization. Long thought of only for physical requirements of specification such as those set for nuts and bolts, standards now cover all sorts of issues with clear and present implications for the societal world. For instance, recent European initiatives to standardize medical treatments, healthcare and elderly services are likely to have major implications in terms of potential social dumping, and interference with regulatory frameworks established in law, defined in collective agreements or set out in professional guidelines. The question then 
is: do global corporations seek to standardize the material support enabling the delivery of health services, or rather substantial aspects of the services themselves irrespective of the context of their provision (such as professional competences, clinical processes and patient communication)? If the latter is true, standards unavoidably include contested cultural values and power relations, including labour processes.

The third dimension is the 'spatial continuum' where the jurisdictions that support the system of recognition of standards overlap. While international standardization is driven by attempts to homogenize and clearly differentiate technical specifications across national jurisdictions in order to reach a higher level of regulatory convergence, it faces a plurality of standards. It rests on the dual nature of sovereignty: 'the juridical expression of the principle that divides the planet into clearly demarcated lines of authority and responsibility' on the one hand, and 'the foundation of the national and international law of contract' required by capitalism on the other (Palan 2003, p. 86). From this view, compliance to standards needs hybrid spaces that reinforce such dual nature of sovereignty. Their recognition rests both on the territorial inscription of sovereignty as well as on the transnational guarantees given to the principle of contract inviolability in a world of globalized capitalism. This is why, for instance, only one standard-setting body per country is eligible to membership in the ISO, even if many of them are non-governmental bodies identified as the 'most representative of standardisation in their country'. At the same time, compliance to standards first and foremost rests on their use by market actors across the globe. As we have seen, a flurry of standards are set and used away from any defined system of national representation and delegation, and are nevertheless entrenched in sovereign contract law. Sustainability labels used by global corporations in global value chains are cases in point, such as the Roundtable for Sustainable Palm Oil (RSPO), or the Global Reporting Initiative (GRI) guidelines on presentation of information. As a final point, it should be noted that, in the absence of harmonized regulation or standards, mutual recognition of standards and regulations reflects a step further toward the transnational plane of the law of contract on which the power projection of global corporations rests. Mutual recognition is in fact designed to ensure that governments recognize each other's standards and accept results of testing, inspection, certification or accreditation bodies in specified industries. In Europe, for instance, products not subject to technical harmonization at the EU level should in principle be freely exchangeable as long as they conform to domestic specifications and regulations of a member state. This is one of the key issues of the regulatory convergence sought by trade deals such as TTIP, TPP and CETA.

\section{CONCLUSIONS}

This chapter has provided insights on how and why global corporations uphold considerable leverage in setting standards in their own interest; not only in shaping innovation, but more broadly in designing market regulation that would traditionally be seen as part of the public domain. In the face of the role played by consumers and employees using and recognizing these standards, some scholars regard such corporate dominance, together with the lack of proper representation and actual participation from labour and consumer interests, as likely to undermine claims to legitimacy made by 
standardization bodies (Farquhar 2006; Wilcock and Colina 2007). As Bamberg points out, "standardization is characterized by a paradox of "large minorities." The two biggest groups concerned (370 million consumers, including 165 million salaried employees, in the EU) are in the minority on standardization committees . . . if represented at all' (Bamberg 2004, p. 13).

The chapter shows, however, that global corporations can rely on such standards to exercise a form of alternative authority to conventional state regulation and intergovernmental agreements (see, for a related discussion, Chapter 22 by May in this volume). It argues that the authority of standards benefits from a peculiar form of ambiguity defining the actors involved in standard-setting procedures, the wide range of issues concerned, and the territorial space through which an extensive use of standards may be recognized as a legitimate definition of market access by sovereign states. This is what I call the 'transnational hybrid authority' of standards.

This chapter draws attention to the lack of fully reliable and systematic data on the use of standards - and hence, their recognition - and the participation of distinct categories of stakeholders, such as global corporations, in standard-setting processes. It provides, however, some evidence of the ability of corporate representatives to organize themselves and defend their interests on a truly global level. Another limitation of the analysis is that it does not allow for a review of how global corporations sometimes behave in an opposite way. In such cases, their strong resistance to international standards is not driven by concerns regarding the democratic deficit of the institutions shaping standardization, but by concerns that standards might compete with the market power of their own global brands.

\section{NOTES}

1. For instance, the Swiss Federal Act on Technical Barriers to Trade (946.51 - art. 11) limits state support or direct participation in standards-setting bodies to standards referred in public law and therefore acquiring a status of mandatory state regulation.

2. Among the legal texts of the WTO, see in particular articles 2 and 5, as well as Annex 3 of the TBT Agreement; article X.2b of the GPA Agreement; article 3 of the SPS Agreement; and articles VI and VII of the GATS.

3. Annex 4, Decision of the Committee on Principles for the Development of International Standards, Guides and Recommendations with Relation to Articles 2, 5 and Annex 3 of the Agreement, WTO TBT Triennial Review, WTO Committee on TBT, G/TBT/9; 11 November 2000, p. 24.

\section{REFERENCES}

Abbott, Kenneth W., Philipp Genschel, Duncan Snidal and Bernhard Zangl (eds) (2015), International Organizations as Orchestrators, Cambridge: Cambridge University Press.

Afnor (2016) 'Baromètre international de la normalisation. Position française dans la normalisation internationale', Association française de normalisation (Afnor).

Akerlof, George A. (1970), 'The market for "lemons": quality uncertainty and the market mechanism', Quarterly Journal of Economics, 84 (3), 488-500.

American National Standards Institute (2016), United States Standards Strategy, New York.

Bamberg, Ulrich (2004), 'Le rôle des syndicats allemands dans le processus de normalisation national et européen', Newsletter du BTS, 24-25, 12-16.

Bhabha, Homi K. (1994), The Location of Culture, London: Routledge. 
Blind, Knut and Stefan Gauch (2009), 'Research and standardisation in nanotechnology: evidence from Germany', Journal of Technology Transfer, 34 (3), 320-342.

Borraz, Olivier (2007), 'Governing standards: the rise of standardization processes in France and in the EU', Governance, 20 (1), 57-84.

Bratton, Benjamin (2015), The Stack: On Software and Sovereignty, Cambridge, MA: MIT Press.

Brunsson, Nils and Bengt Jacobsson (2000), A World of Standards, Oxford: Oxford University Press.

Busch, Lawrence (2011), Standards. Recipes for Reality, Cambridge, MA: MIT Press.

Cai, Phoenix X.F. (2016), 'Regulatory coherence and standardization mechanisms in the Trans-Pacific Partnership', British Journal of American Legal Studies, 5 (2), 505-538.

Cargill, Carl F. and Sherrie Bolin (2007), 'Standardization: a failing paradigm', in Shane Greenstein and Victor Stanga (eds), Standards and Public Policy, Cambridge: Cambridge University Press, pp. 296-328.

Choi, Dong-Geun (2013), 'Measuring the changes of the US influence in global standards-setting', Standards Engineering, 65 (3), 1-7.

Cutler, A Claire, Virginia Haufler and Tony Porter (eds) (1999), Private Authority and International Affairs, New York: SUNY Press.

Czaya, Axel and Wilfried Hesser (2001), 'Standardization systems as indicators of mental, cultural and socio-economic states', Knowledge, Technology, and Policy, 14 (3), 2440.

David, Paul A. (1985), 'Clio and the economics of QWERTY', American Economic Review, 75 (2), 332-337.

De Ville, Ferdi and Gabriel Siles-Brugge (2016), TTIP: The Truth about the Transatlantic Trade and Investment Partnership, London: Polity Press.

Djelic, Marie-Laure and Frank den Hond (2014), 'Symposium on multiplicity and plurality in the world of standards', Business and Politics, 16 (1), 67-77.

Dudouet, François-Xavier, Delphine Mercier and Antoine Vion (2006), 'Politiques internationales de normalisation: Quelques jalons pour la recherche empirique', Revue Française de science politique, 56 (3), 367-392.

Egan, Michelle (2001), Constructing a European Market: Standards, Regulation, and Governance, Oxford: Oxford University Press.

Egyedi, Tineke (2005), 'Beyond consortia, beyond standardization? Redefining the consortium problem', in Kai Jacobs (ed.), Advanced Topics in Information Technology Standards and Standardization Research, London: IGI publishing, pp. $91-110$.

EIM Business \& Policy Research (2009), 'Access to standardisation. Study for the European Commission, Enterprise and Industry Directorate-General. Final report', Zoetermeer, Netherlands.

European Commission (2016a), Standardisation package. European Standardsfor the 21 st Century. Communication from the Commission to the European Parliament, the Council, the European Social and Economic Committee and the Committee of the Regions, 1 June, $\operatorname{COM}(2016) 358$ final.

European Commission (2016b), Report from the Commission to the European Parliament and the Council on the implementation of the Regulation (EU) No 1025/2012 from 2013 to $2015 \mathrm{COM}(2016) 212$ final, 1 June, Brussels.

EXPRESS (2010), 'Standardization for a competitive and innovative Europe: a vision for 2020: The expert panel for the review of the European standardisation system', available at: http://www.anec.eu/attachments/ Definitive\%20EXPRESS\%20report.pdf.

Farquhar, Bruce J. (2006), 'Consumer representation in international standards', Consumer Policy Review, 16 (1), 26-30.

Fliess, Barbara, Frédéric Gonzales, Jeonghoi Kim and Raymond Schonfeld (2010), 'The use of international standards in technical regulation', OECD Trade Policy Papers, Working Paper No 102, Paris.

Frydman, Benoît (2014), 'Prendre les standards et les indicateurs au sérieux', in Fydman, Benoit and Arnaud Van Wayenberger (eds), Gouverner par les standards et les indicateurs, Bruxelles: Bruylant, pp. 33-82.

Graz, Jean-Christophe (2015), 'Standardizing services: transnational authority and market power', in Kees van der Pijl (ed.), Handbook of the International Political Economy of Production, Cheltenham, UK and Northampton, MA, USA: Edward Elgar Publishing, pp. 132-148.

Graz, Jean-Christophe and Christophe Hauert (2014), 'Beyond the transatlantic divide: the multiple authorities of standards in the global political economy of services', Business and Politics, 16 (1), 113-150.

Graz, Jean-Christophe and Andreas Nölke (eds) (2008), Transnational Private Governance and its Limits, London: Routledge.

Guzzini, Stefano and Iver B. Neumann (eds) (2012), The Diffusion of Power: International Political Economy meets Foucault, London: Palgrave Macmillan.

Hallström, Kristina Tamm (2004), Organizing International Standardization: ISO and the IASC in Quest of Authority, Cheltenham, UK and Northampton, MA, USA: Edward Elgar Publishing.

Hauert, Christophe (2010), 'Where are you? Consumers' associations in standardization: a case study on Switzerland', International Journal of IT Standards and Standardization Research, 8 (1), 11-27.

Hauert, Christophe, Marc Audétat, Danielle Bütschi Häberlin, Jean-Christophe Graz and Alain Kaufmann (2016), 'Les arènes de la normalisation internationale à l'épreuve de la participation: le projet INTERNORM', Participations, 1 (14), 207-235. 
JISC (2013), 'Japan's Standardization Policy 2013', Tokyo: Japanese Industrial Standards Committee, Ministry of Economy Trade and Industry.

Latour, Bruno (1991), Nous n’avons jamais été modernes: Essai d'anthropologie symétrique, Paris: La Découverte. Magnette, Paul (2017), CETA: Quand l'Europe déraille, Waterloo: Luc Pire.

Mattli, Walter and Tim Büthe (2011), The New Global Rulers: The Privatization of Regulation in the World Economy, Princeton, NJ: Princeton University Press.

Mock, Dave (2005), The Qualcomm Equation: How a Fledgling Telecom Company Forged a New Path to Big Profits and Market Dominance, New York: American Management Association (AMACOM).

Morikawa, Mari and Jason Morrison (2004), 'Who develops ISO standards? A survey of participation in ISO's international standards development processes', Oakland, CA: Pacific Institute for Studies in Development, Environment, and Security.

Murphy, Craig and JoAnne Yates (2009), The International Organization for Standardization (ISO): Global Governance through Voluntary Consensus, London: Routledge.

National Science and Technology Council (2011), 'Federal engagement in standards activities to address national priorities: background and proposed policy recommendations', Washington, DC: Subcommittee on Standards National Science and Technology Council.

OECD (2016), International Regulatory Co-operation: The Role of International Organisations in Fostering Better Rules of Globalisation, Paris: Organisation for Economic Co-operation and Development.

Palan, Ronen (2003), The Offshore World: Sovereign Markets, Virtual Places, and Nomad Millionaires, Ithaca, NY: Cornell University Press.

Payne, Anthony and Nicola Phillips (eds) (2014), Handbook of the International Political Economy of Governance, Cheltenham, UK and Northampton, MA, USA: Edward Elgar Publishing.

Pitschas, Christian (2016), 'Transatlantic Trade and Investment Partnership (TTIP): the devil in disguise or a golden opportunity to build a transatlantic marketplace?', British Journal of American Legal Studies, 5 (2), $315-340$.

Ponte, Stefano, Peter Gibbon and Jakob Vestergaard (eds) (2011), Governing through Standards: Origins, Drivers and Limitations, Houndmills: Palgrave Macmillan.

Shapiro, Carl and Hal R. Varian (1999), 'The art of standard wars', California Management Review, 41 (2), 8-32.

Swann, G.M. Peter (2010), 'The economics of standardization: an update', London: UK Department of Business, Innovation and Skills (BIS).

Tate, Jeffrey (2001), 'National varieties of standardization', in Peter Hall and David Soskice (eds), Varieties of Capitalism. The Institutional Foudations of Comparative Advantage, Oxford: Oxford University Press, pp. 442-473.

Tilley, Aaron (2016), 'Microsoft, Qualcomm and Intel start playing nice on "internet of things" standards', Forbes, 19 February.

Timmermans, Stefan and Steven Epstein (2010), 'A world of standards but not a standard world: toward a sociology of standards and standardization', Annual Review of Sociology, 36, 69-89.

Viardot, Eric, Mostafa Hashem Sherif and Jin Chen (2016), 'Managing innovation with standardization: an introduction to recent trends and new challenges', Technovation, 48-49, 1-3.

Vogel, David (1995), 'National regulation in the global economy', in David Vogel (ed.), Trading Up Consumer and Environmental Regulation in a Global Economy, Cambridge, MA: Harvard University Press, pp. 1-23.

Wilcock, Anne and Alejandra Colina (2007), 'Consumer representation on consensus standards committees: a value-added practice', International Journal of Services and Standards, 3 (1), 1-17.

Winn, Jane K (2009), 'Globalization and standards: the logic of two-level games', I/S: A Journal of Law and Policy for the Information Society, 5 (2), 185-219.

World Trade Organization (2012), World Trade Report 2012: Trade and Public Policies: A Closer Look at Non-Tariff Measures in the 21st Century, Geneva: WTO.

Zuckerman, Amy (1996), International Standards Desk Reference: Your Passport to World Markets: Iso 9000 , Ce Mark, Qs-9000, Ssm, Iso 14000, Q 9000, American, European and Global Standards Systems, New York: American Management Association.

Zumbansen, Peer C. (2015), 'The incurable constitutional itch: transnational private regulatory governance and the woes of legitimacy', in Michael A. Helfand (ed.), Negotiating State and Non-State Law: The Challenge of Global and Local Legal Pluralism, Cambridge: Cambridge University Press, pp. 83-110. 
